This document is confidential and is proprietary to the American Chemical Society and its authors. Do not copy or disclose without written permission. If you have received this item in error, notify the sender and delete all copies.

\title{
Sunscreens as a new source of metals and nutrients to coastal waters
}

\begin{tabular}{|r|l|}
\hline Journal: & Environmental Science \& Technology \\
\hline Manuscript ID & es-2019-02739u.R1 \\
\hline Manuscript Type: & Article \\
\hline Date Submitted by the & 10 -Jun-2019 \\
\hline Complete List of Authors: & $\begin{array}{l}\text { Rodriguez-Romero, Araceli; Universidad de Cantabria, Chemistry and } \\
\text { Process \& Resource Engineering } \\
\text { Ruiz-Gutierrez, Gema; Universidad de Cantabria, Chemistry and Process } \\
\text { \& Resource Engineering } \\
\text { Viguri Fuente, Javier Rufino; Universidad de Cantabria, Chemistry and } \\
\text { Process \& Resource Engineering } \\
\text { Tovar-Sanchez, Antonio; Instituto de Ciencias Marinas de Andalucia }\end{array}$ \\
\hline
\end{tabular}

\section{SCHOLARONE ${ }^{\text {m }}$ Manuscripts}




\section{Sunscreens as a new source of metals and nutrients to coastal waters}

Araceli Rodríguez-Romero, ${ }^{*} \dagger$ Gema Ruiz-Gutiérrez, ${ }^{\dagger}$ Javier R. Viguri, ${ }^{\dagger}$ and Antonio TovarSánchez*

$\dagger$ Green Engineering and Resources Group (GER), Department of Chemistry and Process \& Resource Engineering, ETSIIT, University of Cantabria, Av. Castros s/n, 39005 Santander, Cantabria, Spain.

$\$$ Department of Ecology and Coastal Management, Institute of Marine Sciences of Andalusia, ICMAN (CSIC), Campus Río San Pedro, 11510 Puerto Real, Cádiz, Spain.

\section{$1 \quad$ ABSTRACT}

2 Studies detailing the environmental impact of sunscreen products on coastal ecosystems are

3 considered a high priority. In the present study we have determined the release rate of dissolved

4 trace metals $(\mathrm{Al}, \mathrm{Cd}, \mathrm{Cu}, \mathrm{Co}, \mathrm{Mn}, \mathrm{Mo}, \mathrm{Ni}, \mathrm{Pb}$ and $\mathrm{Ti})$ and inorganic nutrients $\left(\mathrm{SiO}_{2}, \mathrm{P}-\mathrm{PO}_{4}{ }^{3-}\right.$ and

$5 \mathrm{~N}^{-\mathrm{NO}_{3}}{ }^{-}$) from a commercial sunscreen in seawater, and the role of UV radiation in the mobilization

6 of these compounds. Our results indicate that release rates are higher under UV light conditions

7 for all compounds and trace metals except $\mathrm{Pb}$. We have developed a kinetic model to establish the

8 release pattern and the contribution to marine coastal waters of dissolved trace metals and

9 inorganic nutrients from sunscreen products. We conservatively estimate that sunscreen from

10 bathers is responsible for an increase of dissolved metals and nutrients ranging from $7.53 \times 10^{-4} \%$

11 for Ni up to $19.8 \%$ for Ti. Our results demonstrate that sunscreen products are a significant source

12 of metals and inorganic nutrients to coastal waters. The normally low environmental 
13 concentrations of some elements (e.g. P) and the toxicity of others (e.g. Pb) could be having a

14 serious adverse effect on marine ecology in the Mediterranean Sea. This risk must not be ignored.

15 Keywords: Sunscreen, ultraviolet light, metals, inorganic nutrients and kinetic modeling.

\section{INTRODUCTION}

18 Tourism plays a very significant role in the development of coastal areas, especially in

19 Mediterranean countries where, tourism, especially "beach \& sun" holidays, has been breaking

20 annual records in recent years ${ }^{1}$. However, tourism can lead to unwanted impacts if it is not

21 developed in a sustainable way. The quality of the water, the rich biodiversity and the natural

22 resources in general of the marine and coastal areas are often threatened by the uncontrolled

23 development of tourism that leads to excessive risk. The sustainable use of our oceans and seas,

24 ensured by the sustainable development and growth of the coastal regions, is considered a priority

25 by the European Union ${ }^{2}$.

26 Research-based knowledge of the ecological impact of tourism and recreational activities on the

27 marine ecosystem is very scarce. For example, seasonal trends in tourism can mediate the timing

28 and effects of the eutrophication of effluent from wastewater; much higher loads are caused by

29 periodic and often predictable surges in the number of visitors at specific times of the year (mainly

30 during summer); and the impacts can extend over a wide area and have effects in areas at

31 considerable distance from the main areas where tourists congregate ${ }^{3}$.

32 Amongst the many chemicals and emerging pollutants that enter the sea and cause adverse

33 ecological effects, sunscreens products in particular are attracting attention in the scientific

34 community, as well as generating significant media coverage in the last few years. 
35 Recently, the interest in these commercial products has increased among scientists and the general

36 public. In the area of human health, experts now insistently recommend the correct application of

37 these products as being essential to help prevent skin cancer due to exposure to ultraviolet (UV)

38 sunlight. In the area of the marine environment, concern has emerged in recent years about the

39 potential hazards for marine ecology caused by the chemical UV filters, both organic (e.g.

40 oxybenzone and octinoxate) and inorganic ( $\mathrm{Ti}$ and $\mathrm{Zn}$ nanoparticles), that are incorporated as

41 ingredients in the formulation of sunscreens. These chemicals are released when the product comes

42 into contact with seawater ${ }^{4}$. On this latter topic, the study of the behavior of metal nanoparticles

43 included in sunscreen formulation and released in the sea is considered very important. For

44 example, it has been reported that nanoparticles can co-occur with other chemicals in aquatic

45 environment and increase the toxicity of them on organisms ${ }^{5}$.

46 Although knowledge is improving about the degradation of individual chemical agents in

47 sunscreens, such as organic (e.g. octyl dimethyl-p-aminobenzoate) and inorganic $\left(\mathrm{TiO}_{2}\right.$

48 nanoparticles) UV filters ${ }^{6,7}$, there is a lack of research that describes the potential release and

49 behavior of chemical ingredients from the total sunscreen matrix in marine waters ${ }^{8}$. This is due to

50 the special physical-chemical characteristics of seawater and the complex matrix of the sunscreen

51 products. For example, the high ionic strength of seawater and organic matter content could

52 promote the agglomeration and sedimentation of nanoparticles ${ }^{5}$. In addition to UV filters,

53 commercial sunscreen contains a great variety of other chemical ingredients that make each of

54 these cosmetic products a complex matrix that is difficult to manage both analytically and

55 environmentally. Sunscreens have also been identified as a significant source of inorganic

56 nutrients, mainly $\mathrm{PO}_{4}{ }^{3-}$, in coastal and marine waters, raising the possibility of algae blooms in

57 oligotrophic waters ${ }^{8}$. Furthermore, these cosmetics can be a source of high-risk substances such 
58 as metals ${ }^{9}$, many of which (i.e. $\mathrm{Al}, \mathrm{Zn}, \mathrm{Mg}, \mathrm{Fe}, \mathrm{Mn}, \mathrm{Cu}, \mathrm{Cr}$ and $\mathrm{Pb}$ ) have been detected and 59 quantified in sunscreens ${ }^{8,10}$.

60 It has been demonstrated that concentrations of some of these compounds from sunscreens released 61 in coastal water (i.e. $\mathrm{PO}_{4}{ }^{3-}, \mathrm{NH}_{4}{ }^{+}, \mathrm{NO}_{3}{ }^{-}$and Ti) vary during the course of a day, and this could be 62 associated with variations in the beachgoers activities and changes in solar radiation ${ }^{8}$. However, 63 reliable knowledge on the role of sunlight on the release in seawater of the main ingredients found

64 in sunscreen products has not yet been addressed. Sunlight is known to be an important factor in 65 the transformation of chemicals in surface waters ${ }^{11}$. This is especially important in the coastal 66 environment, which is considered to be a "hotspot" of photochemical processes that lead to the 67 transformation of dissolved and particulate compounds ${ }^{11,12,13}$.

68 During the aging process and because their hydrophobic characteristics, sunscreen forms stable 69 colloidal residues in seawater, including macroscopic aggregates, agglomerates and submicronic 70 fractions ${ }^{14}$. These compounds can be released to the aqueous phase in the form of dissolved 71 chemicals and colloids through various physical-chemical processes. This study evaluates the 72 differences of dissociation of inorganic compounds/elements under UV light and dark exposure, 73 the kinetics behind the mobilization into the seawater phase, and the amount of these released 74 products included in the fraction $<0.22 \mu \mathrm{m}$. In particular, experiments on the kinetics of release, 75 using commercial sunscreen, have been conducted in the lab, under controlled UV light and 76 temperature conditions, to evaluate the susceptibility of sunscreen to release metals $(\mathrm{Al}, \mathrm{Cd}, \mathrm{Cu}$, $77 \mathrm{Mn}, \mathrm{Mo}, \mathrm{Ni}, \mathrm{Pb}, \mathrm{Co}$ and $\mathrm{Ti})$ and nutrients $\left(\mathrm{Si}-\mathrm{SiO}_{2}, \mathrm{P}-\mathrm{PO}_{4}{ }^{3-}\right.$ and $\left.\mathrm{N}-\mathrm{NO}_{3}{ }^{-}\right)$into seawater. Kinetic 78 models are proposed to explain the behavior and variability in seawater of the chemicals studied.

79 This model-based approach offers a valuable potential tool to better understand the risks associated 80 with inorganic nutrients and metals released from sunscreens in the marine coastal ecosystem. 
MATERIALS AND METHODS

\section{Seawater collection}

83 Surface water was collected in March 2018 from a zodiac in an offshore area of the Mediterranean

84 Sea (Málaga, Spain; 36.48N, 4.51W) using a peristaltic pump and pumped through acid-cleaned

85 Teflon tubing coupled to a C-flex tubing (for the Cole-Parmer peristaltic pump head), filtered

86 through an acid-cleaned polypropylene cartridge filter $\left(0.22 \mu \mathrm{m}\right.$; MSI, Calyx $\left.{ }^{\circledR}\right)$ and placed in a 25

87 L low-density polyethylene acid-cleaned plastic carboy. Seawater were filtered in order to avoid

88 the influences that the presence of natural organic matter and organisms could introduce in the

89 elements mobility. The collected seawater was transported to the laboratory and kept at $4^{\circ} \mathrm{C}$ in dark

90 conditions prior to experiments. Seawater was stored no longer than two weeks. Prior to

91 performing the experiments, subsamples of seawater were collected for analysis of dissolved

92 inorganic nutrients and metals content.

\section{Metals and inorganic nutrients release kinetics experiment}

94 In this study, we examined the effects of ultraviolet light $(280-400 \mathrm{~nm})$ on the kinetics of release

95 of nutrients and metals from one of the most recommended and used commercial sunscreen type

96 (i.e. sun protection milk spray application type with a SPF of 50) (e.g.

97 https://www.consumerreports.org/cro/sunscreens.htm). Laboratory experiments were carried

98 under dark and UV light conditions, mimicking the natural night-time and mid-day conditions

99 respectively, of a Mediterranean coastal area during the summer season. The selection of this

100 particular commercial sunscreen tested was based on: the sun protection factor (SPF 50), the

101 presence of nanoparticles of titanium dioxide among the ingredients; and the format of the

102 sunscreen product, i.e. sun protection milk spray, which has been demonstrated to cause higher

103 toxicity to marine organisms ${ }^{8}$. Metals and inorganic nutrients composition of the selected 
104 sunscreen were characterized prior experiments. In both kinetics experiments, $0.8 \mathrm{~g}$ of sunscreen

105 was added to $400 \mathrm{~mL}$ of seawater in quartz glass vessels (0.5 L capacity). Quartz vessels were

106 used to ensure the penetration of UV light into the seawater sample. During selected time periods

107 (between 0 and $24 \mathrm{~h}$ exposure), vessels were gently stirred (simulating movement of water by

108 waves) using a magnetic stirrer, at a controlled temperature of $24^{\circ} \mathrm{C}$ representative of seawater

109 temperature in the Mediterranean Sea during the summer ${ }^{15,16}$. Temperature in the experiments was

110 maintained by cooling water circulation (Polyscience AD07R-40 refrigerated circulating bath).

111 The time periods selected were 0 (immediately after the sunscreen was added), 0.25, 0.5, 1, 3, 6,

11212 and 24 hours.

113 Samples were exposed to UV radiation of $37.25 \pm 3.59 \mathrm{~W} \mathrm{~m}^{-2}$ (average $\pm \mathrm{SE}$ ) using a high-pressure

114 UV lamp (OSRAM, ULTRA VITALUX $\left.{ }^{\odot}, 300 \mathrm{~W}\right)$, comparable to the UV component of sunlight.

115 This type of lamp has been used in previous studies related to the degradation of chemical

116 compounds ${ }^{17}$ and in the study of sun protection factors ${ }^{18}$, among others. The UV light intensity

117 during this experimental period was analogous to the mid-day sunlight in the coastal city of

118 Málaga $^{19}$ and corresponds to an ultraviolet index between 8 and10 (considered very high and

119 typical of a summer day on the Mediterranean coast) for the same period in the same place. An

120 UV light meter (UVA-UVB PCE-UV34) was used for UV measurements during the experiment.

121 A diagram of the experimental device under UV light conditions is given in Supporting 122 Information (SI) in Figure S1.

123 In both experiments, at the end of each selected time period, the sample was removed from the

124 quartz chamber and filtered through a $0.22 \mu \mathrm{m}$ pore-size filter for dissolved chemical analyses, as

125 it represents the soluble and bioavalability fraction. However, we are aware that the filtered

126 solution can contains both, dissolved species and particulate matter $<0.22 \mu \mathrm{m}$ that are released 
127 from the sunscreen after the experimental exposure. From each sample two subsamples were

128 obtained, one for inorganic nutrient analysis (kept at $-20^{\circ} \mathrm{C}$ until analysis) and another subsampled

129 for trace metal analysis (acidified to $\mathrm{pH} 1.5-2$ with $\mathrm{HCL} 1 \mathrm{M}$ ) and kept at $4^{\circ} \mathrm{C}$ until

130 preconcentration and analysis. Blanks (seawater sample without sunscreen) were obtained for each

131 selected period and under both light conditions.

\section{Analytical Procedure}

133 Sunscreen characterization. Metals $(\mathrm{Al}, \mathrm{Cd}, \mathrm{Cu}, \mathrm{Mn}, \mathrm{Mo}, \mathrm{Ni}, \mathrm{Pb}, \mathrm{Co}$ and $\mathrm{Ti}$ ) and total $\mathrm{P}$ and $\mathrm{Si}$

134 in sunscreen were analyzed in triplicate by ICP-MS (PerkinElmer ELAN DRC-e) after prior 135 chemical digestion, following the method described by Páscoa ${ }^{20}$

136 Seawater chemical analysis. The concentrations of inorganic nutrients $\left(\mathrm{Si}_{-} \mathrm{SiO}_{2}, \mathrm{P}^{-} \mathrm{PO}_{4}{ }^{3-}, \mathrm{N}-\right.$

$137 \mathrm{NO}_{2}^{-}, \mathrm{N}^{-} \mathrm{NO}_{3}^{-}$) in seawater samples were determined by colorimetric techniques ${ }^{21}$ using an

138 autoanalyzer (Skalar San++ System). The accuracy of the analysis was established using reference

139 material for nutrients in seawater (KANSO CRM Japan), with recoveries of 102.5\%, 108.3\%, $14096.4 \%$ and $103.9 \%$ for $\mathrm{Si}-\mathrm{SiO}_{2}, \mathrm{P}_{-} \mathrm{PO}_{4}{ }^{3-}, \mathrm{N}^{-\mathrm{NO}_{2}}{ }^{-}$and $\mathrm{N}-\mathrm{NO}_{3}{ }^{-}$. Concentrations of $\mathrm{Al}, \mathrm{Mn}$ and $\mathrm{Ti}$, 141 in seawater were determined directly by ICP-MS (PerkinElmer ELAN DRC-e). Samples for the 142 analysis of $\mathrm{Cd}, \mathrm{Co}, \mathrm{Cu}, \mathrm{Mo}, \mathrm{Ni}$ and $\mathrm{Pb}$ content were previously pre-concentrated using a liquid143 organic extraction method with APDC/DDDC ${ }^{22}$ and analyzed by ICP-MS (PerkinElmer ELAN 144 DRC-e). The accuracy of metal analysis was checked by the following certified coastal water 145 reference materials for trace metals: CASS-4 N RC-CNRC. The recoveries reported were 93\%, $14698 \%, 103 \%, 93 \%, 93 \%$ and $92 \%$ for $\mathrm{Cd}, \mathrm{Cu}, \mathrm{Mn}, \mathrm{Mo}, \mathrm{Pb}$ and Co respectively. All the sampling 147 and analytical operations were carried out in accordance with clean techniques for trace metals. 148 All chemical analyses were measured in duplicate. The results are expressed as nmol $\mathrm{L}^{-1}$. 


\section{Modeling}

151 The data obtained from the laboratory experiments was modeled and the corresponding parameters

152 were calculated by using Aspen Custom Modeler software (Bedford, Massachusetts, USA) which

153 solves rigorous models and simultaneously estimates parameters. Furthermore, Aspen Custom

154 Modeler gives the statistics values that allow to compare the experimental values of concentration

155 with the values from the mathematical model. The correlation coefficient $\left(\mathrm{R}^{2}\right)$, relative standard 156 deviation (RSD) and relative and absolute error were used to check the validity of the model. This

157 tool has been successfully used previously by the authors to model release behavior of 158 contaminants from sediments to seawater ${ }^{23}, 24$. The model parameters were adjusted using an 159 NL2SOL algorithm for the least-square minimization of the deviation between the experimental 160 and theoretical data.

\section{RESULTS AND DISCUSSION}

163 Sunscreen composition. The concentrations of the elements studied in the commercial sunscreen 164 selected and the seawater used in this study are given in Table 1 . Titanium $\left(1.48 \times 10^{7} \mu \mathrm{g} \mathrm{kg}^{-1}\right)$ 165 and $\mathrm{Al}\left(1.67 \times 10^{6} \mu \mathrm{g} \mathrm{kg}^{-1}\right)$ are the two metals with the highest concentration in the sunscreen. 166 Titanium is present in sunscreen as $\mathrm{TiO}_{2}$ and $\mathrm{TiO}_{2}$-nanoparticles, both used as UV filter. The 167 sunscreen contains $\mathrm{Al}$ in the form of $\mathrm{Al}(\mathrm{OH})_{3}$, usually used as an opacifying and viscosity168 controlling agent ${ }^{25}$ and, in some sunscreens, to reduce the agglomeration of the $\mathrm{TiO}_{2}$ nanoparticles 169 and their catalytic activity in the sunscreen when it is exposed to UV light, and to prevent harmful 170 effects on skin ${ }^{26,27}$. Results of the analysis also show the presence of other metals in relevant 171 concentrations, including $\mathrm{Pb}, \mathrm{Mn}, \mathrm{Cu}, \mathrm{Mo}, \mathrm{Ni}, \mathrm{Cd}$, and $\mathrm{Co}$ (ranging from $743 \mu \mathrm{gg}^{-1}$ for $\mathrm{Pb}$, to $1726.10 \mu \mathrm{g} \mathrm{kg}^{-1}$ for $\mathrm{Co}$ ); these other metals are not described in the sunscreen formulation provided 
173 for users. Metals can be incorporated in cosmetics intentionally because of their function ${ }^{28}$ or

174 indirectly, as result of the breakdown of ingredients that incorporate them ${ }^{29}$ or due to inadequate

175 purification of raw materials that contain metal impurities ${ }^{30}$. Cobalt may be included as ingredient

176 in the composition of the sunscreen, coating the surface of titanium dioxide nanoparticles powders,

177 to improve their properties performance, as colorant and/or as skin conditioning ${ }^{31}$. In previous

178 studies, concentrations of $\mathrm{Al}, \mathrm{Cu}, \mathrm{Mn}, \mathrm{Pb}$, and $\mathrm{Ti}$ in sunscreen products have been reported in a

179 wide range of concentrations $\left(2.20 \times 10^{4}-7.40 \times 10^{4} \mu \mathrm{g} \mathrm{kg}^{-1}\right.$ for $\mathrm{Al} ;<900-5.30 \times 10^{5} \mu \mathrm{g} \mathrm{Kg}^{-1}$ for

$180 \mathrm{Cu} ;<200-5.90 \times 10^{5} \mu \mathrm{g} \mathrm{Kg}^{-1}$ for $\mathrm{Mn} ; 27.0-1.75 \times 10^{3} \mu \mathrm{g} \mathrm{Kg}{ }^{-1}$ for Pb; and $60.0-18.5 \times 10^{6} \mu \mathrm{g} \mathrm{Kg}^{-1}$

181 for $\mathrm{Ti})^{9,10}$.

182 Table 1. Trace element concentrations in the commercial sunscreen tested and in the seawater

183 (dissolved, $<0.22 \mu \mathrm{m}$ ) used in the release kinetics experiments.

\begin{tabular}{cll}
\hline Element & $\begin{array}{l}\text { Sunscreen } \\
\text { content } \\
\left(\boldsymbol{\mu g} \mathbf{~ k g}^{-1}\right)\end{array}$ & $\begin{array}{l}\text { Seawater } \\
\text { content } \\
\left(\mathbf{n m o l ~ L}^{-1}\right)\end{array}$ \\
\hline $\mathrm{Al}$ & $1.67 \times 10^{6}$ & 235 \\
$\mathrm{Cd}$ & 16.7 & 0.0552 \\
$\mathrm{Co}$ & 6.10 & 0.0693 \\
$\mathrm{Cu}$ & 170 & 1.14 \\
$\mathrm{Mn}$ & 254 & 5.27 \\
$\mathrm{Mo}$ & 137 & 92.6 \\
$\mathrm{Ni}$ & 47.5 & 2.43 \\
$\mathrm{~Pb}$ & 743 & 0.0703 \\
$\mathrm{Ti}$ & $1.48 \times 10^{7}$ & 33.5 \\
$\mathrm{P}-\mathrm{PO}_{4}{ }^{3-}$ & $3.15 \times 10^{5}$ & 73.5 \\
$\mathrm{Si}-\mathrm{SiO}_{2}$ & $3.83 \times 10^{6}$ & 894 \\
$\mathrm{~N}-\mathrm{NO}_{3}{ }^{-}$ & n.a & 81.8 \\
\hline
\end{tabular}


185 Element concentrations in sunscreen are expressed as $\mu \mathrm{g} \mathrm{kg}^{-1}$. Metal and inorganic nutrient 186 concentrations in seawater are expressed as $\mathrm{nmol} \mathrm{L}^{-1}$. Phosphorus and silicon were measured as 187 total $\mathrm{P}$ and $\mathrm{Si}$ form in the sunscreen matrix. n.m means not measured.

189 Significant concentrations of phosphorous, $\mathrm{P}\left(3.15 \times 10^{5} \mu \mathrm{g} \mathrm{kg}-1\right)$, and silicon, $\left(3.83 \times 10^{6} \mu \mathrm{g} \mathrm{kg}^{-1}\right)$, 190 were also measured in the sunscreen matrix. These nutrients are commonly used in the 191 formulations of these cosmetics. Phosphorus is found in the form of pentasodium ethylenediamine 192 tetramethylene phosphonate, used as a chelating and controlling viscosity agent ${ }^{32}$. Silica, in small 193 concentrations, is also used in these cosmetics for coating $\mathrm{TiO}_{2}$ nanoparticles ${ }^{26}$ and to improve 194 viscosity ${ }^{33}$. Although we were not able to measure the amount of nitrogen compounds in 195 sunscreen, $\mathrm{N}$ is present, in amounts depending on the product, in the form of the following 196 nitrogenated compounds: bis-ethylhexyloxyphenol methoxyphenyl triazine, octocrylene, 197 ethylhexyl triazone and drometrizole trisiloxane, used also as UV filters ${ }^{34-37}$ and as chelating and 198 viscosity controlling agents ${ }^{32}$.

199 The concentrations of metals and inorganic nutrients measured in the seawater used for the release 200 kinetics experiment (Table 1) are of the same order of magnitude as in Mediterranean coastal 201 seawater ${ }^{38}$.

202 Trace element release. The experimental results obtained for the release of metals and inorganic 203 nutrients from sunscreen to the seawater compartment are plotted in Figure 1. Our results show a 204 clear release of $\mathrm{Al}, \mathrm{Cu}, \mathrm{Mn}, \mathrm{Ti}, \mathrm{Si}-\mathrm{SiO}_{2}$ and $\mathrm{P}_{-} \mathrm{PO}_{4}{ }^{3-}$ from sunscreen into seawater. However, the 205 release pattern observed for $\mathrm{Cd}, \mathrm{Mo}, \mathrm{Ni}, \mathrm{Co}$ and $\mathrm{N}-\mathrm{NO}_{3}{ }^{-}$was not clear; the concentrations of $\mathrm{N}-$ $206 \mathrm{NO}_{2}{ }^{-}$in treatment samples were below the detection limit $(<0.03 \mu \mathrm{M})$. 
207 In general, concentrations of released elements were affected by length of time and exposure to 208 UV light. The highest release concentrations of $\mathrm{Al}, \mathrm{Cd}, \mathrm{Co}, \mathrm{Cu}, \mathrm{Ti}, \mathrm{Si}-\mathrm{SiO}_{2}$ and $\mathrm{P}_{-} \mathrm{PO}_{4}{ }^{3-}$ measured 209 were under UV light exposure. Only Mn, Mo and Ni did not show significant ( $\mathrm{p}>0.05$; t-test) 210 differences in release rate between light conditions (Figure 1). Average release rates in the first 24 211 hours were calculated as $(\mathrm{C} 24 \mathrm{~h}-\mathrm{C} 0 \mathrm{~h}) / 24\left[\mathrm{nmol} \mathrm{L}^{-1} \mathrm{~h}^{-1}\right]$. Release rates decreased in the order Si$212 \mathrm{SiO}_{2}>\mathrm{P}_{-}-\mathrm{PO}_{4}{ }^{-3}>\mathrm{Al}>\mathrm{Ti}>\mathrm{Mo}>\mathrm{Mn}>\mathrm{Cu}>\mathrm{Co}$, under UV light and $\mathrm{Al}>\mathrm{SiO}_{2}=\mathrm{P}_{-}-\mathrm{PO}_{4}{ }^{-3}>\mathrm{Mo}>\mathrm{Mn}>$

$213 \mathrm{Cu}>\mathrm{Cd}>\mathrm{Pb}$, under dark conditions. Aluminum, $\mathrm{SiO}_{2}$ and $\mathrm{P}^{-\mathrm{PO}_{4}}{ }^{-3}$ had the highest average release 214 rates in both cases. Under $\mathrm{UV}$ light conditions $\mathrm{Cd}, \mathrm{Pb}$ and $\mathrm{N}^{-\mathrm{NO}_{3}-}$ showed maximum 215 concentration ( $\mathrm{t} \leq 30$ minutes: $1.79 \mathrm{nmol} \mathrm{L}^{-1}, 0.180 \mathrm{nmol} \mathrm{L}^{-1}$ and $2250 \mathrm{nmol} \mathrm{L}^{-1}$, respectively). 216 After 3 hours of experiment, the concentration declined notably $\left(0.120 \mathrm{nmol} \mathrm{L}^{-1}, 0.0970 \mathrm{nmol} \mathrm{L}^{-1}\right.$ 217 and $163 \mathrm{nmol} \mathrm{L}^{-1}$, respectively), reaching a near-equilibrium condition at the end of the exposure. 218 Only $\mathrm{Pb}$ clearly increased the concentration more under dark condition than under UV light 219 exposure, reaching a maximum of $0.290 \mathrm{nmol} \mathrm{L}^{-1}$ after $12 \mathrm{~h}$. For these elements (i.e. $\mathrm{Cd}, \mathrm{Pb}$ and $220 \mathrm{~N}-\mathrm{NO}_{3}{ }^{-}$) dissolution and desorption are favored in the absence of photoreactions. Although more 221 experiments would be necessary to determine the reason for the decrease in concentration of $\mathrm{Pb}$, 222 it is reasonable to conclude that the mechanism for this is adsorption to some of the organic 223 compounds included in the sunscreen formulation. In the case of $\mathrm{N}^{-\mathrm{NO}_{3}}{ }^{-}$, its action as an oxidant, 224 mediated by photocatalytic reactions, could explain the considerable decrease seen in its 225 concentration in seawater ${ }^{39}$. 


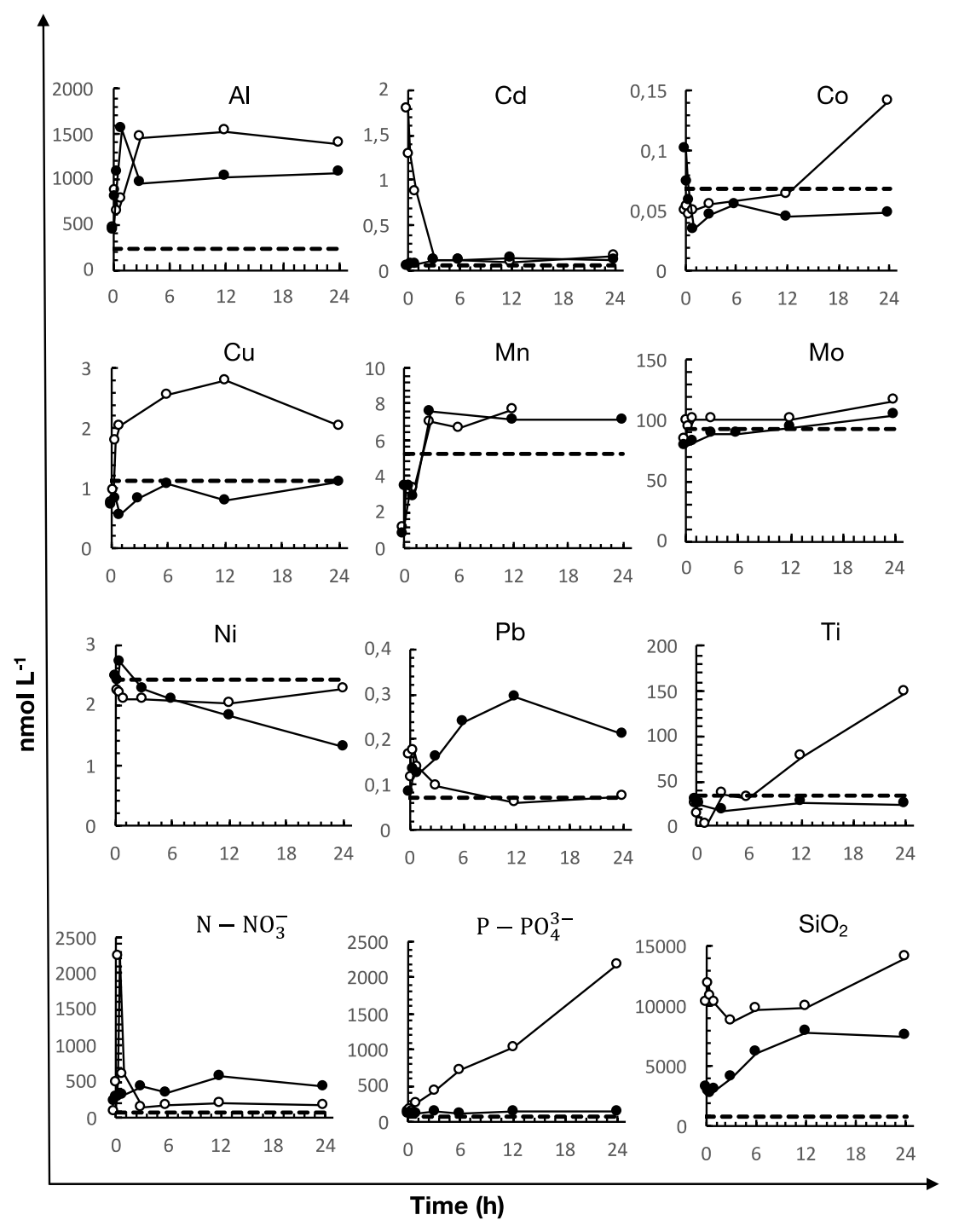

231 Figure 1. Kinetics of dissolved trace metals and inorganic nutrients released from a commercial 232 sunscreen under UV light (white dots) and under dark conditions (black dots). The horizontal, 233 dashed line depicts the initial concentration of the element in seawater.

\section{Kinetic model of elements release}

236 We have calculated a kinetic model to establish the release pattern and the contribution of trace

237 metals and inorganic nutrients from sunscreen to marine coastal waters. Sunscreen in seawater

238 forms stable colloidal residues that could include macroscopic aggregates, agglomerates and 
239 submicronic fractions ${ }^{14}$. The high proportion of organic material in the colloidal residues released 240 from the sunscreen controls the behavior, surface properties and structure of the colloids. 241 Nanoparticles, organic and inorganic chemicals from the sunscreen formulation can interact 242 through several complex processes under different aging times and conditions ${ }^{5,40-42}$; aggregation 243 rates increase with ionic strength ${ }^{43}$. Figure 2 shows the schematic representation of the chemicals 244 and nanoparticles release proposed in the kinetic scheme (Eq. 4) of aging sunscreen in the seawater 245 environment. The proposed model does not consider the interactions of the studied elements in the 246 air-water and water-sediment interface neither the interactions with natural suspension matter from 247 seawater and organisms. In relation to the nanoparticles, only the behavior of the measured 248 submicronic fraction $(<0.22 \mu \mathrm{m})$ in seawater is considered. Metals, elements associated with 249 nanoparticles and phosphorous, showed different experimental release behavior and therefore 250 three different kinetic schemes are proposed (Eq. 4). Metals not associated to nanoparticles (Al, $251 \mathrm{Cd}, \mathrm{Cu}, \mathrm{Mn}, \mathrm{Mo}, \mathrm{Ni}$ and $\mathrm{Pb}$ ) are contained mainly inside the organic material; subsequently they 252 are released to the seawater and finally, after an aging period, they can be adsorbed onto the organic 253 material forming a stable colloidal suspension. The elements associated to the nanoparticles (Ti, $254 \mathrm{Co}, \mathrm{Si}$ ) are initially linked to the organic chemicals due to the hydrophobic character. After a first 255 step, they are unlinked inside the organic material, and later, with a delay of $6 \mathrm{~h}$, released to the 256 seawater with an important concentration increasing during the rest of the experiment ( $6 \mathrm{~h}$ to $24 \mathrm{~h}$ ); 257 an additional adsorption-desorption stage of these elements can be considered. Phosphorus in 258 sunscreen can be photo-mineralized to inorganic species of $\mathrm{P}_{-} \mathrm{PO}_{4}{ }^{3-43}$. 


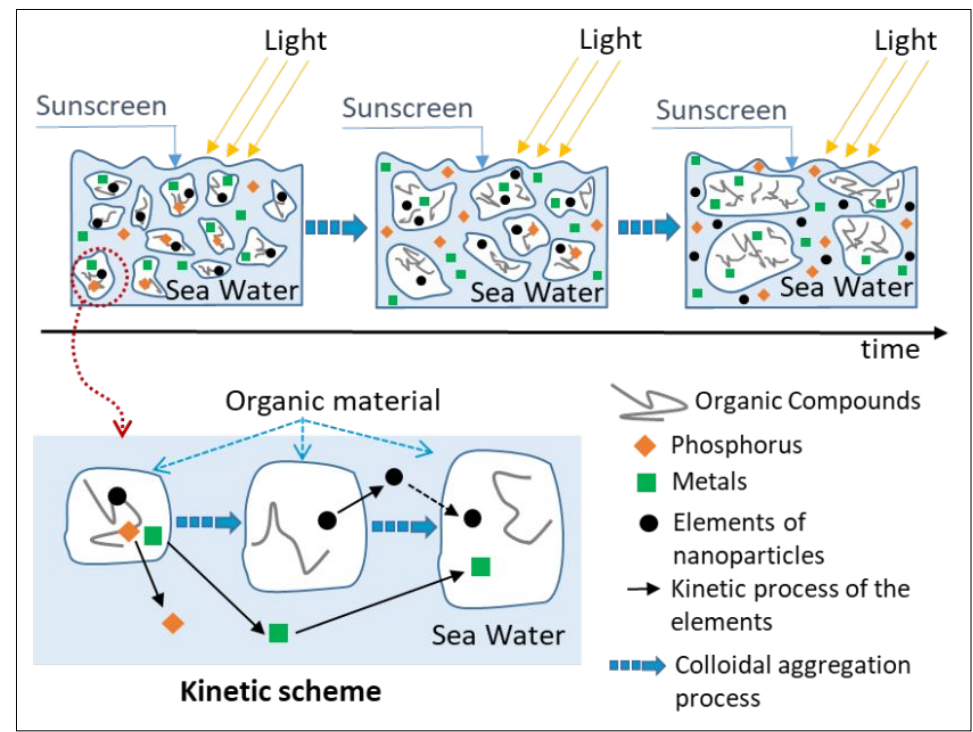

261 Figure 2. Representation of the dynamic release of the studied chemical elements from sunscreen 262 to seawater under UV light exposure and the aging time, according to the kinetic scheme 263 considered in the eq. 4.

265 The degradation of organic chemical ingredients of sunscreen has previously been found to follow 266 a pseudo-first-order model ${ }^{39,46}$. In the present work, the release processes of nutrients and metals 267 from sunscreen in seawater can be modeled considering pseudo-first-order reactions (Eq. 1):

$$
r_{i, j}=k_{i, j}\left[X_{i}\right]
$$

268 where $r_{i, j}$ is the reaction rate, $k_{i, j}$ is the rate coefficient of the metal or nutrient $\mathrm{i}$ in the reaction $\mathrm{j}$,

269 and $\left[X_{i}\right]$ is the concentration of the reactant $\mathrm{i}$ of each reaction. The concentration of metals or

270 nutrients in seawater in each experiment performed at constant volume can be determined by Eq.2:

$$
\frac{d\left[X(a q)_{i}\right]}{d t}=\sum_{j=1}^{n} r_{i, j}-\sum_{k=1}^{m} r_{i, k}
$$

271 where $\mathrm{j}$ is the $\mathrm{n}$ reactions that release $\mathrm{X}(\mathrm{aq})$ and $\mathrm{k}$ the $\mathrm{m}$ reactions that adsorb $\mathrm{X}(\mathrm{aq})$ from the 272 seawater. The release and adsorption of the components in seawater can take place under total or 
273 equilibrium reaction. In the latter case, the equilibrium constant of component $i$ can be determined 274 by Eq. 3 :

$$
K e_{i, j}=\frac{k_{i, j}}{k_{i,-j}}
$$

275 where the subscript $\mathrm{j}$ represents the direct reaction of release, and the subscript $-\mathrm{j}$ the adsorption.

276 In accordance with the release mechanisms described (Figure 2), three different kinetic schemes

277 (Eq.4) are considered to describe the behavior of metals, elements associated with nanoparticles

278 ( $\mathrm{Ti}, \mathrm{Co}$ and $\mathrm{Si}$ ), and phosphorus, respectively. In the present work, the liberation of $\mathrm{NO}_{3}{ }^{-}$cannot

279 be modeled because of the lack of data on the concentration of total nitrogen and its speciation in 280 sunscreen.

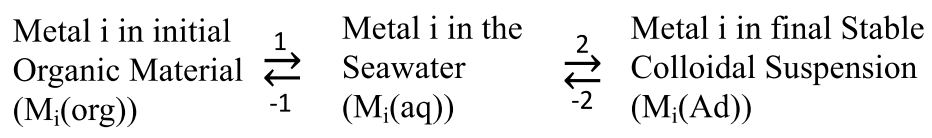

\begin{tabular}{|c|c|c|c|c|c|c|}
\hline $\begin{array}{l}\text { Element } \\
\text { i-nanoparticle in } \\
\text { Organic chemical } \\
\text { inside the Organic } \\
\text { Material } \\
\left(\mathrm{X}_{\mathrm{i}}-\mathrm{NP}-\mathrm{OC}(\text { org) })\right.\end{array}$ & $\underset{-1}{\stackrel{1}{\rightleftarrows}}$ & $\begin{array}{l}\text { Element } \\
\text { i-nanoparticle } \\
\text { unliked in } \\
\text { Organic Material } \\
\left(\mathrm{X}_{\mathrm{i}}-\mathrm{NP}(\text { org })\right)\end{array}$ & $\underset{-2}{\stackrel{2}{\rightleftarrows}}$ & $\begin{array}{l}\text { Element } \\
\text { i-nanoparticle } \\
\text { the Seawater } \\
\left(\mathrm{X}_{\mathrm{i}}-\mathrm{NP}(\mathrm{aq})\right)\end{array}$ & $\underset{-3}{\stackrel{3}{\rightleftarrows}}$ & $\begin{array}{l}\text { Element } \\
\text { i-nanoparticle in final } \\
\text { Stable Colloidal } \\
\text { Suspension } \\
\left(\mathrm{X}_{\mathrm{i}}-\mathrm{NP}(\mathrm{Ad})\right)\end{array}$ \\
\hline
\end{tabular}

$\begin{array}{lll}\text { P in Organic } & 1 \\ \text { Material } & \stackrel{P_{4}{ }^{3-} \text { in the }}{\rightleftarrows} & \begin{array}{l}\text { Peawater } \\ \text { (P(org) })\end{array}\end{array}$

281 The values of kinetic constants were estimated considering: the resolution of the mass balances

282 of the eq. 2 , the kinetic scheme of the eq. 4 , the initial concentration values of elements, and the

283 experimental data of concentration vs. time. The rate coefficients and equilibrium constants of the

284 kinetic reactions estimated, together with the correlation coefficients $\left(\mathrm{R}^{2}\right)$ and relative standard 285 deviations (RSD) of the elements released over time, are shown in Table 2. Figure 3 shows the 286 experimental and modeled release of elements over time. The simulated curves adequately fit the 287 experimental results. The release of metals from the sunscreen into seawater can be described by 
288 a total reaction for all metals $\left(K e q_{i, 1}=0\right.$ inTable 2$)$, except for $\mathrm{Cu}$ in the experiment with UV

289 light, and for $\mathrm{Cd}$ in the experiment in darkness. However, their adsorption onto organic material

290 is described by an equilibrium reaction $\left(K e q_{i, 2} \neq 0\right)$ for $\mathrm{Cd}, \mathrm{Mn}, \mathrm{Ni}$ and $\mathrm{Pb}$ in the presence of UV

291 light, and for $\mathrm{Al}, \mathrm{Cd}, \mathrm{Cu}$ and $\mathrm{Mn}$ in darkness. Elements in the nanoparticles (Ti, Co and $\mathrm{Si}$ ) are

292 released first to the organic chemicals, later to the seawater and finally adsorbed in the final stable

293 colloidal suspension, except for cobalt for which no adsorption is observed. All reactions of Ti, Co

294 and $\mathrm{Si}$ (except for Co without UV light conditions where $K e q_{i, 2} \neq 0$ ), can be described by total

295 reactions $\left(K e q_{i, j}=0\right.$ in Table 2$)$. The proposed model predicts reasonably well the observed delay

296 in the mobility of $\mathrm{Ti}$, Co and $\mathrm{Si}$ after short exposure times (Figure 3 ). The $\mathrm{k}_{\mathrm{i}, 1}$ and $\mathrm{k}_{\mathrm{i}, 2}$ kinetic

297 constants obtained for $\mathrm{Ti}, \mathrm{Co}$ and $\mathrm{Si}_{-} \mathrm{SiO}_{2}$ (Table 2) were equal to each element. This pattern was

298 different from the rest of the studied elements and confirmed the similar origin of these three

299 elements in the system. The release of phosphorous compounds from the organic material to the

300 seawater can be described by a first order reaction.

302 Table 2. Estimated kinetic rate coefficients $k_{i, j}$ and equilibrium constants $K e q_{i, j}$ for each

303 contaminant in all the assays. The correlation coefficients $\left(\mathrm{R}^{2}\right)$ and relative standard deviation

304 (RSD) parameters for the relation between the experimental and simulated released concentrations

305 using the proposed model are also shown.

306

\begin{tabular}{|c|c|c|c|c|c|c|c|c|}
\hline \multirow{2}{*}{$\begin{array}{l}\text { Metals: } \\
\text { Parameter }\end{array}$} & & $\mathrm{Al}$ & $\mathrm{Cd}$ & $\mathrm{Cu}$ & $\mathrm{Mn}$ & Mo & $\mathrm{Ni}$ & $\mathrm{Pb}$ \\
\hline & \multicolumn{8}{|c|}{$\mathrm{M}_{\mathrm{i}}(\mathrm{org}) \underset{-1}{\stackrel{1}{\rightleftarrows}} \mathrm{M}_{\mathrm{i}}(\mathrm{ac}) \underset{-2}{\stackrel{2}{\rightleftarrows}} \mathrm{M}_{\mathrm{i}}(\mathrm{ad})$} \\
\hline \multirow{6}{*}{$\begin{array}{l}\text { with } \\
\text { UV light }\end{array}$} & $\mathrm{k}_{\mathrm{i}, 1}\left(\mathrm{~h}^{-1}\right)$ & 0.00647 & 0.989 & 0.465 & 0.310 & 2.47 & 0.00671 & $9.87 \times 10^{-4}$ \\
\hline & $\mathrm{Keq}_{\mathrm{i}, 1}$ & --- & --- & 0.937 & --- & --- & --- & --- \\
\hline & $\mathrm{k}_{\mathrm{i}, 2}\left(\mathrm{~h}^{-1}\right)$ & 0.508 & 1.07 & 0.0283 & 1.31 & --- & 0.444 & 0.263 \\
\hline & $\mathrm{Keq}_{\mathrm{i}, 2}$ & --- & 19.0 & --- & 0.567 & --- & 0.226 & 5.44 \\
\hline & RSD & 0.183 & 0.164 & 0.148 & 0.132 & 0.563 & 0.023 & 0.208 \\
\hline & $\mathrm{R}^{2}$ & 0.911 & 0.984 & 0.932 & 0.964 & 0.610 & 0.890 & 0.788 \\
\hline
\end{tabular}




\begin{tabular}{|c|c|c|c|c|c|c|c|c|}
\hline \multirow{6}{*}{$\begin{array}{l}\text { without } \\
\text { UV light }\end{array}$} & $\mathrm{k}_{\mathrm{i}, 1}\left(\mathrm{~h}^{-1}\right)$ & 0.0332 & 0.201 & 0.0365 & 0.443 & 0.337 & $5.22 \times 10^{-5}$ & 0.00960 \\
\hline & $\mathrm{Keq}_{\mathrm{i}, 1}$ & --- & 0.622 & --- & --- & --- & --- & --- \\
\hline & $\mathrm{k}_{\mathrm{i}, 2}\left(\mathrm{~h}^{-1}\right)$ & 3.45 & 0.0501 & 0.215 & 0.102 & 0.0232 & 0.0263 & 0.246 \\
\hline & $\mathrm{Keq}_{\mathrm{i}, 2}$ & 158 & 0.131 & 4.02 & 0.625 & --- & --- & --- \\
\hline & RSD & 0.228 & 0.0548 & 0.220 & 0.253 & 0.779 & 0.0512 & 0.168 \\
\hline & $\mathrm{R}^{2}$ & 0.701 & 0.989 & 0.497 & 0.876 & 0.742 & 0.945 & 0.888 \\
\hline \multicolumn{2}{|c|}{ Element-nanoparticle: } & \multicolumn{2}{|c|}{$\mathrm{Ti}$} & & Co & \multicolumn{2}{|c|}{$\mathrm{Si}$} & \\
\hline \multicolumn{2}{|l|}{ Parameter } & \multicolumn{7}{|c|}{$X_{i}-N P-O C($ org $) \underset{-1}{\stackrel{1}{\rightleftarrows}} X_{i}-N P($ org $) \underset{-2}{\stackrel{2}{\rightleftarrows}} X_{i}-N P(a q) \underset{-3}{\stackrel{3}{\rightleftarrows}} X_{i}-N P(A d)$} \\
\hline \multirow{8}{*}{$\begin{array}{l}\text { with } \\
\text { UV light }\end{array}$} & $\mathrm{k}_{\mathrm{i}, 1}\left(\mathrm{~h}^{-1}\right)$ & \multicolumn{3}{|c|}{0.00650} & 0.0518 & \multicolumn{2}{|c|}{0.0132} & \\
\hline & $\mathrm{Keq}_{\mathrm{i}, 1}$ & \multicolumn{3}{|c|}{---} & --- & \multicolumn{2}{|c|}{---} & \\
\hline & $\mathrm{k}_{\mathrm{i}, 2}\left(\mathrm{~h}^{-1}\right)$ & \multicolumn{3}{|c|}{0.00641} & 0.0513 & \multicolumn{2}{|c|}{0.0134} & \\
\hline & $\mathrm{Keq}_{\mathrm{i}, 2}$ & \multicolumn{3}{|c|}{---} & --- & \multicolumn{2}{|c|}{---} & \\
\hline & $\mathrm{k}_{\mathrm{i}, 3}\left(\mathrm{~h}^{-1}\right)$ & \multicolumn{2}{|c|}{3.70} & & --- & \multicolumn{2}{|c|}{0.0310} & \\
\hline & $\mathrm{Keq}_{\mathrm{i}, 3}$ & \multicolumn{2}{|c|}{---} & & --- & \multicolumn{2}{|c|}{---} & \\
\hline & RSD & \multicolumn{2}{|c|}{0.171} & & 0.120 & \multicolumn{2}{|c|}{0.0599} & \\
\hline & $\mathrm{R}^{2}$ & \multicolumn{2}{|c|}{0.975} & & 0.944 & \multicolumn{2}{|c|}{0.789} & \\
\hline & $\mathrm{k}_{\mathrm{i}, 1}\left(\mathrm{~h}^{-1}\right)$ & \multicolumn{2}{|c|}{$1.84 \times 10^{-5}$} & & 0.731 & \multicolumn{2}{|c|}{0.493} & \\
\hline & $\mathrm{Keq}_{\mathrm{i}, 1}$ & \multicolumn{2}{|c|}{---} & & --- & \multicolumn{2}{|c|}{---} & \\
\hline & $\mathrm{k}_{\mathrm{i}, 2}\left(\mathrm{~h}^{-1}\right)$ & \multicolumn{2}{|c|}{0.453} & & 0.342 & & 897 & \\
\hline without & $\mathrm{Keq}_{\mathrm{i}, 2}$ & & - & & 0.22 & & & \\
\hline UV light & $\mathrm{k}_{\mathrm{i}, 3}\left(\mathrm{~h}^{-1}\right)$ & & .465 & & --- & & & \\
\hline & $\mathrm{Keq}_{\mathrm{i}, 3}$ & & - & & --- & & & \\
\hline & RSD & & .0394 & & 0.093 & & & \\
\hline & $\mathrm{R}^{2}$ & & .928 & & 0.956 & & & \\
\hline Phosphoru & & & & & $\mathrm{PO}_{4}^{-}$ & & & \\
\hline Parameter & & $\mathrm{P}$ (org & $\stackrel{1}{\stackrel{1}{\rightleftarrows}} \mathrm{PO}_{4}^{3-}($ & & & & & \\
\hline & $\mathrm{k}_{\mathrm{i}, 1}\left(\mathrm{~h}^{-1}\right)$ & 1.71 & & & & & & \\
\hline with & $\mathrm{Keq}_{\mathrm{i}, 1}$ & --- & & & & & & \\
\hline UV light & RSD & 0.0895 & & & & & & \\
\hline & $\mathrm{R}^{2}$ & 0.993 & & & & & & \\
\hline & $\mathrm{k}_{\mathrm{i}, 1}\left(\mathrm{~h}^{-1}\right)$ & $8.31 \mathrm{x}$ & & & & & & \\
\hline without & $\mathrm{Keq}_{\mathrm{i}, 1}$ & --- & & & & & & \\
\hline UV light & RSD & 0.0805 & & & & & & \\
\hline & $\mathrm{R}^{2}$ & 0.603 & & & & & & \\
\hline
\end{tabular}




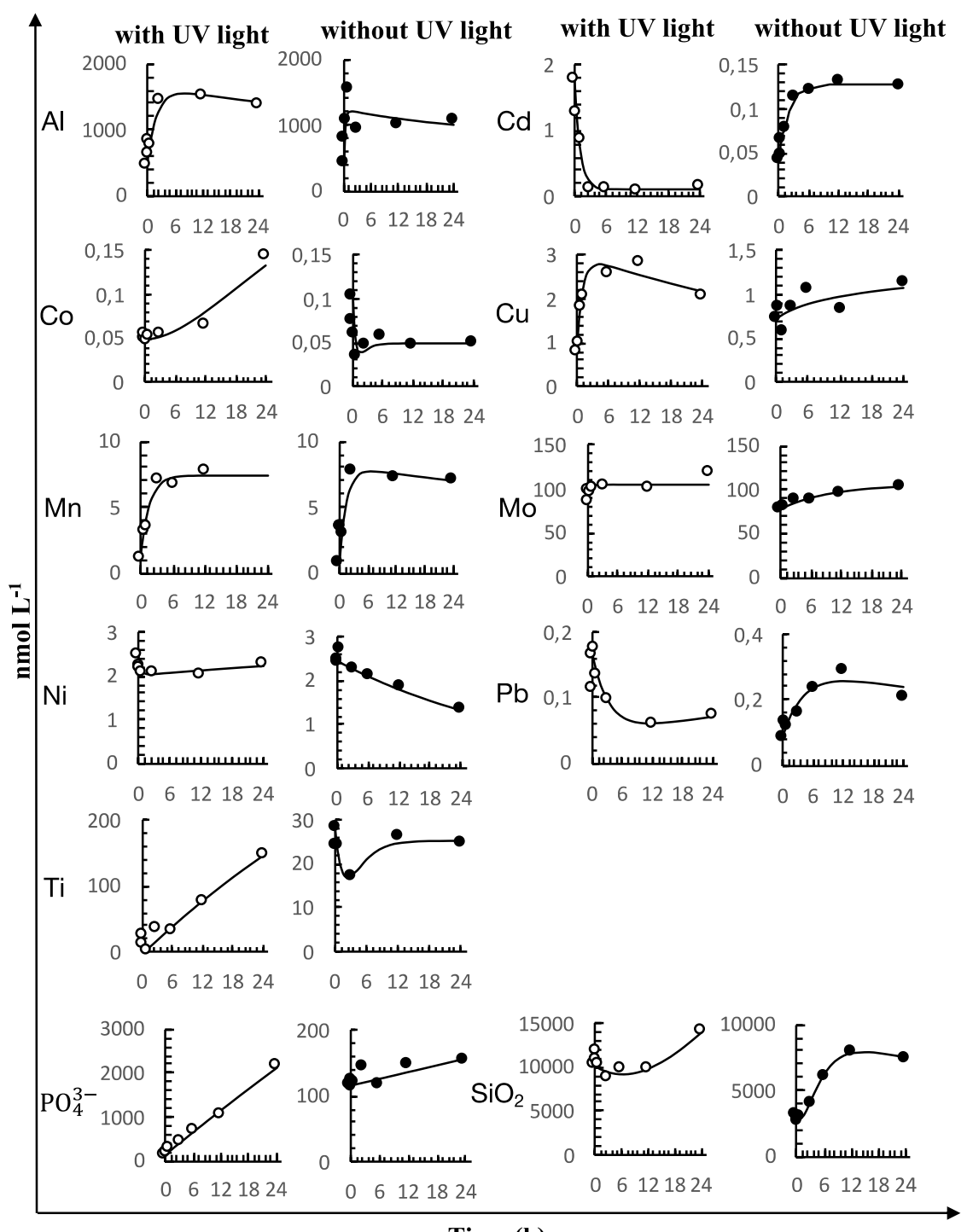

Time (h)

Figure 3. Experimental concentration $\left(\mathrm{mmol} \mathrm{L}^{-1}\right)$ over time of the dissolved metals and nutrients

312 under UV light conditions (white dots), under dark conditions (black dots) and simulated by the

313 proposed model (solid line).

Figure 4 shows the parity plot obtained for the validation of the proposed model in terms of the

316 concentrations of the studied element released, at any time and in both UV light and darkness

$317(\mathrm{n}=157)$. The correlation coefficient $\left(\mathrm{R}^{2}\right)$ between the experimental values and the values simulated

318 by the model was 0.979 , which indicates a good correspondence between the experimental and 
319 predicted concentrations. A good fit of the proposed model is also confirmed by the fact that $92 \%$

320 of the experimental data lie within a model relative error of $\pm 20 \%$, although larger deviations were

321 noticed at concentrations lower than $0.4 \mathrm{nmol} \mathrm{L}^{-1}$.

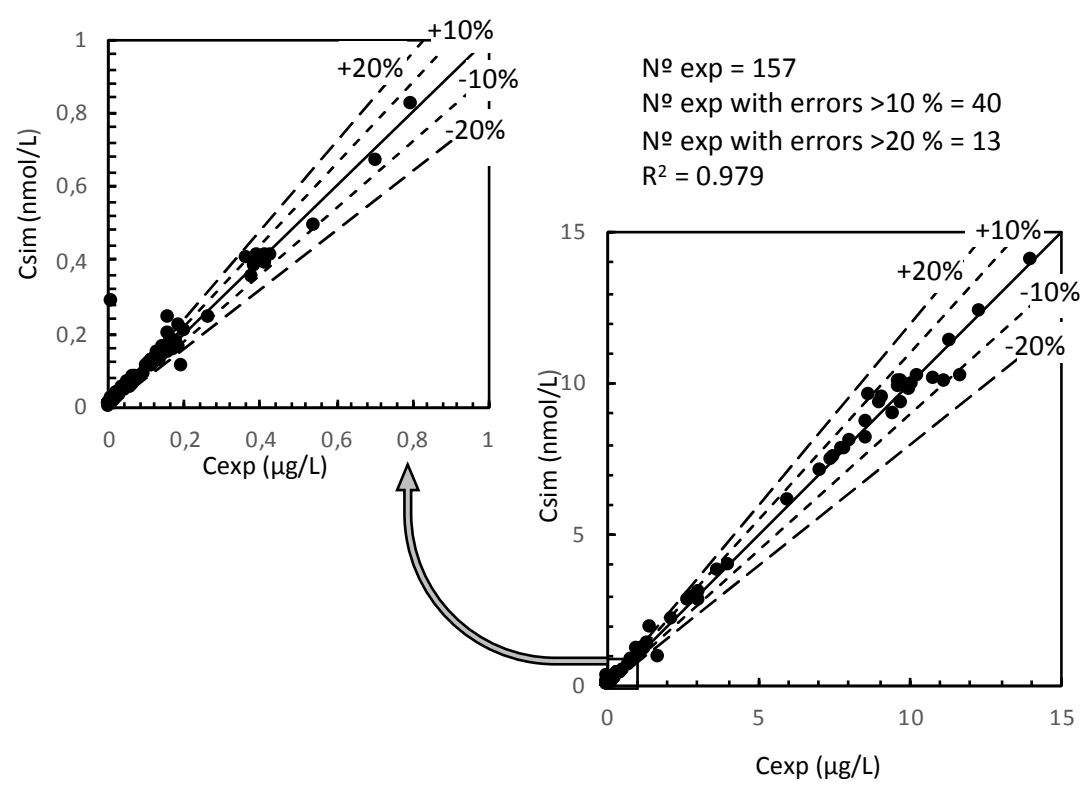

322

324 Figure 4. Parity plots of the seawater concentrations from the experimental (Cexp) and simulated

325 (Csim) results of the elements under study. The data number $(\mathrm{N})$ and percentage variationexplained value (R2) are also shown.

327 The good fit obtained confirms that the proposed model predicts reasonably well the release of

328 contaminants from sunscreen to seawater; an estimation of the maximum concentrations of each

329 element released after 24 hours, the kinetic rate coefficients and equilibrium rate constants are

330 obtained. The obtained model predicts the release of metals and inorganic nutrients under the

331 studied experimental conditions. This model is an useful tool to predict and assess the risk of

332 sunscreens in the sea.

333 The environmental impact and the consequent potential negative effects of sunscreens ingredients

334 in coastal waters is considered a research priority ${ }^{2,}{ }^{4}$. Several studies have demonstrated the 
335 numerous effects that individual ingredients have on marine organisms, including the rapid 336 bioaccumulation of UV filters in bivalves, bleaching of corals, and a severe decrease in the

337 recruitment and survival in sea urchin, and others ${ }^{7,47-50}$. However, identifying sunscreens as a 338 source of releasing metals and nutrients in the marine system and the potential impact of input, has 339 not yet been addressed.

340 Using the kinetic constants calculated from our experiment results, we have plotted in Figure 5 the 341 estimated increase of concentration of metals and inorganic nutrients derived from the beachgoers 342 during bath in a typical Mediterranean beach on a summer day. To obtain these values, we have 343 made the following assumptions: 1) that one beachgoer uses $1 \mathrm{mg} / \mathrm{cm}^{2}$ of sunscreen per 344 application, i.e. half of the internationally-recommended amount of sunscreen for a single 345 application ${ }^{51}$, about $18 \mathrm{~g}$ of sunscreen per person; 2) that at least $25 \%$ of the amount of sunscreen 346 applied is washed off during each instance of sea-bathing ${ }^{52,53}$; 3 ) the mass flow of sunscreen per 347 hour added to the sea water $\left(\mathrm{kg}\right.$ sunscreen $\left.\mathrm{h}^{-1}\right)$ is determined according to the number of bathers 348 and baths and 4) total volume of sea water of $2.58 \times 10^{-4} \mathrm{~m}^{3}$, off a typical Mediterranean beach ${ }^{8}$. 349 The parameters used for this simulation are given in SI in Tables S1 and S2. Simulated increase in 350 the concentration (nmol L-1 and \%) of metals and inorganic nutrients released in a summer day 351 compared to their background levels in seawater (Table 1) is shown in nmol L-1 as well as in 352 percentage in SI in Table S3.

353 The increase of dissolved metals released by the tested sunscreen in seawater could range between $3547.5 \times 10^{-4} \%$ for $\mathrm{Ni}$ and $20 \%$ for Ti. Titanium, $\mathrm{Al}$, and $\mathrm{Pb}$ are the metals that present the most 355 increase in their concentrations, at $20 \%, 4 \%$ and $0.2 \%$, respectively. Several trace metals, at low 356 concentrations (e.g. $\mathrm{Co}, \mathrm{Mn}, \mathrm{Ni}$, and $\mathrm{Cu}$ ), play a key biological role in the sea, regulating the 357 biogeochemical function in marine organisms, while others, such as $\mathrm{Pb}$ and $\mathrm{Cd}$, could negatively 
358 affect the ecosystem ${ }^{54,55}$. Thus, small increments of the dissolved concentrations of these metals 359 could have an effect on the marine biota. For example, it has been demonstrated that the induction 360 of phytoplankton cell death in the Mediterranean Sea population is already detectable at 361 concentrations, of both $\mathrm{Cd}$ and $\mathrm{Pb}$, of $89-96 \mathrm{pmol} \mathrm{L}^{-1}{ }^{56}$. Therefore, the release of metals from 362 sunscreen of the order calculated in this study for a typical beach in the Mediterranean Sea, could 363 be having a toxic effect on phytoplankton growth. Although the toxicity of Al to marine biota has 364 hardly been investigated, studies have detected the very high sensitivity of the diatom Ceratoneis 365 closterium to this metal ( $72-\mathrm{h} \mathrm{IC}_{10}$ at $593 \mathrm{nmol} \mathrm{L}^{-1}$ of $\left.\mathrm{Al}\right)^{57}$. For this metal, a cumulative increase 366 of $4 \%$ in Al levels in seawater for a few days could be having a largely unknown effect that surely 367 requires further research. A quantifiable oxidative stress response in the mussel Mytillus 368 galloprovincialis has been observed after $24 \mathrm{~h}$ of exposure to Ti at $58.5 \mathrm{nmol} \mathrm{L}^{-1}$ (corresponding 369 to $0.2 \mathrm{~g} \mathrm{~L}^{-1}$ of sunscreen) under laboratory conditions ${ }^{49}$. The predicted final $\mathrm{Ti}$ concentration 370 calculated in our study in seawater $\left(45 \mathrm{nmol} \mathrm{L}^{-1}\right)$ after a summer day, is close to that level, and 371 therefore is another good reason for the potential effect of $\mathrm{Ti}$ on the marine environment to be 372 determined.

373 With respect to the inorganic nutrients in sea water, sunscreen may increase the concentrations of 374 dissolved $\mathrm{P}_{-} \mathrm{PO}_{4}{ }^{3-}$ and $\mathrm{Si}_{-} \mathrm{SiO}_{2}$ by $0.2 \%$, and $0.6 \%$ respectively (Figure 5). Although, nitrogen is 375 usually the main limiting nutrient for primary productivity in marine waters ${ }^{58}$, in the Mediterranean 376 Sea the main limiting nutrient of primary productivity is $\mathrm{P}^{-\mathrm{PO}_{4}}{ }^{3-59-61}$. The low availability of 377 phosphorous in the Mediterranean Sea prevents high primary productivity, leading to oligotrophic 378 conditions. The beaches of this Sea are enjoyed by many millions of visitors every year; the 379 Mediterranean received more than 330 million tourists in 2016, making it the largest tourism 
380 destination in the world ${ }^{2}$. Therefore, a significant supplement of $\mathrm{P}_{-} \mathrm{PO}_{4}{ }^{3-}$ from sunscreen use could

381 be having an important and unpredictable ecological effect in the Mediterranean Sea.

382

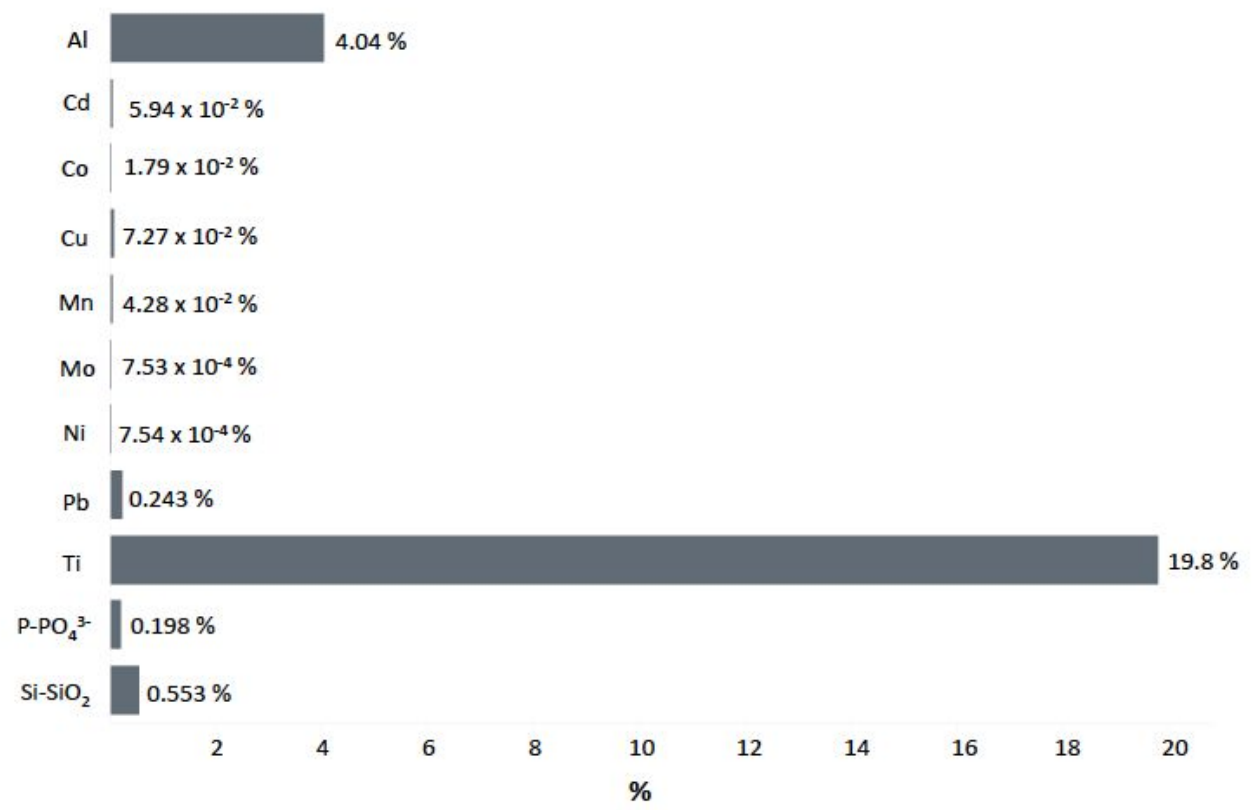

384 Figure 5. Increase (\%) of dissolved metals and inorganic nutrients released from sunscreen after 385 a summer day at a typical Mediterranean beach.

386 We have used a conservative rate of water renewal of $24 \mathrm{~h}$, but longer water residence times of 387 between 3 -15 days have been recorded for some Mediterranean beaches ${ }^{62}$. In the context of these 388 calculations, water renewal is an essential factor that cannot be ignored due to the associated 389 cumulative effect which could increase the percentages of increase of metals and inorganic 390 nutrients in seawater estimated over time.

391 Our study confirms that sunscreen is a potential source of dissolved trace metals and inorganic 392 nutrients in coastal waters. Some dissolved element concentrations do not seem to present large 393 differences in release rates between day and night (i.e. Al, Mo, Ni), whereas others show high 394 release rates in daylight (i.e. $\mathrm{Co}, \mathrm{Cu}, \mathrm{P}_{-} \mathrm{PO}_{4}{ }^{3-}$ and $\mathrm{Ti}$ ) or in darkness (i.e. $\mathrm{Pb}$ ) (Figure 1). Our 395 findings suggest that the mobilization of trace metal and inorganic nutrients from sunscreen to 
396 seawater could be significantly facilitated by the incidence of UV light. UV radiation can penetrate 397 to depths of least 30 meters in coastal areas, and produces about $50 \%$ of total photochemical effects 398 in the marine environment ${ }^{63}$. These effects can change the toxicity of chemicals ${ }^{64}$ and could enable 399 greater bio-availability of those trace metals included in sunscreen, thus causing their 400 bioaccumulation in marine organisms. Furthermore, chemicals contained in sunscreen can react 401 under UV radiation and form new compounds, such as hydrogen peroxide ${ }^{38,65}$.

402 The role of UV light in trace elements release from sunscreen is especially important in the context 403 of the assessment of environmental risk presented by these sun protection products ${ }^{66}$. Although 404 the number of studies made to assess the potential effects of sunscreens on marine biota has been 405 increasing recently, the majority of laboratory studies are conducted without UV light at 406 environmentally-relevant conditions, so they are likely to under-estimate the real impacts that 407 sunscreen-related chemicals may have on the natural environment. Therefore, kinetic release 408 studies of sunscreen products under different scenarios of interaction (i.e. diverse types in terms 409 of chemical-physical characteristics) and exposure to UV light (different intensities) are required 410 for a better understanding of the fate of chemicals released from sunscreen in marine waters. It is 411 essential to predict as accurately as possible their potential effects on the vitally-important coastal 412 marine environment.

\section{ASSOCIATED CONTENT}

\section{Supporting Information}

416 Figure S1. Diagram of the experimental device under UV light conditions.

417 Table S1. Parameters and considerations used for simulating of the evolution of metals, $\mathrm{Si}_{-} \mathrm{SiO}_{2}$ 418 and $\mathrm{P}_{-} \mathrm{PO}_{4}{ }^{3-}$ from tested sunscreen in seawater column. 
419 Table S2. Average number of bathers and flow of sunscreen added to the sea as a function of time,

420 considering the assumptions of table S1.

421 Table S3. Simulated increase in dissolved metals and inorganic nutrients (nmol L-1 and \%) on one

422 summer day compared to their background levels of seawater used in this study (Table 1).

423 This material is available free of charge via the Internet at http://pubs.acs.org.

424 AUTHOR INFORMATION

425 Corresponding Author

426 *Phone: + 34942206707

427 e-mail: araceli.rodriguez@unican.es

428 Notes

429 The authors declare no competing financial interest.

430 ACKNOWLEDGMENTS

431 This work is funded by the University of Cantabria "Proyecto Puente 2017" (PI: J. Viguri)

432 under the SODERCAN and ERDF Operational Program. The authors thank A. Moreno and D.

433 Roque for their support with field seawater sampling, F. Gómez for his support in constructing the 434 experimental device, A. Silio for lamp characterization and I. Carribero for her assistance with 435 chemical analysis. A. Rodríguez-Romero is supported by the Spanish grant Juan de 436 la Cierva Formación (JCI-2015-26873).

\section{$438 \quad$ References}

439 (1) UNWTO Tourism Highlights, 2017 Edition | Tourism Market Trends UNWTO [WWW 440 Document], n.d. URL http://mkt.unwto.org/publication/unwto-tourism-highlights $441 \quad$ (accessed 7.31.18). 
442 (2) Tovar-Sánchez, A.; Sánchez-Quiles, D.; Rodríguez-Romero, A. Massive Coastal Tourism 443 Influx to the Mediterranean Sea: The Environmental Risk of Sunscreens. Sci. Total Environ.

(3) Hardiman, N.; Burgin, S. Recreational Impacts on the Fauna of Australian Coastal Marine

Ecosystems. J. Environ. Manage. 2010, 91

(11), 2096-2108. https://doi.org/10.1016/J.JENVMAN.2010.06.012.

(4) Sánchez-Quiles, D; Tovar-Sánchez, A. Are Sunscreens a New Environmental Risk Associated with Coastal Tourism? Environ. Int. 2015, 83, 158-170. https://doi.org/10.1016/J.ENVINT.2015.06.007.

(5) Naasz, S.; Altenburger, R.; Kühnel, D. Environmental Mixtures of Nanomaterials and Chemicals: The Trojan-Horse Phenomenon and its Relevance for Ecotoxicity. Sci. Total Environ. 2018, 635, 1170-1181. https://doi.org/10.1016/j.scitotenv.2018.04.180.

(6) Sakkas, V.; Giokas, D.; Lambropoulou, D.; Albanis, T. Aqueous Photolysis of the Sunscreen Agent Octyl-Dimethyl-p-Aminobenzoic Acid: Formation of Disinfection Byproducts in Chlorinated Swimming Pool Water. J. Chromatogr. A 2003, 1016 (2), 211222. https://doi.org/10.1016/S0021-9673(03)01331-1.

(7) Sendra, M.; Sánchez-Quiles, D.; Blasco, J.; Moreno-Garrido, I.; Lubián, L. M.; Pérez- 
462

463

464

465

466

467

468

469

470

471

472

473

474

475

476

477

478

479

480

481

(8) Tovar-Sánchez, A.; Sánchez-Quiles, D.; Basterretxea, G.; Benedé, J. L.; Chisvert, A.; Salvador, A.; Moreno-Garrido, I.; Blasco, J. Sunscreen Products as Emerging Pollutants to Coastal Waters. PLoS One 2013, 8 (6), e65451. https://doi.org/10.1371/journal.pone.0065 451.

(9) Zmozinski, A. V.; Pretto, T.; Borges, A. R.; Duarte, Á. T.; Vale, M. G. R. Determination of $\mathrm{Pb}$ and $\mathrm{Cr}$ in Sunscreen Samples by High-Resolution Continuum Source Graphite Furnace Atomic Absorption Spectrometry and Direct Analysis. Microchem. J. 2016, 128, 89-94. https://doi.org/10.1016/j.microc.2016.03.020.

(10) Zachariadis, G. A.; Sahanidou, E. Multi-Element Method for Determination of Trace Elements in Sunscreens by ICP-AES. J. Pharm. Biomed. Anal. 2009, 50 (3), 342-348. https://doi.org/10.1016/J.JPBA.2009.05.003.

(11) Cooper W. J.; Herr F.L. (1987). Introduction and Overview. Chapter 1, pp 1-8. In Photochemistry of Environmental Aquatic Systems. Editors R.G Zika and W.J Cooper; ACS Symposium Series; American Chemical Society: Washington, DC, 1987.

(12) Zafiriou, O. C.; Joussot-Dubien, J.; Zepp, R. G.; Zika, R. G. Photochemistry of Natural Waters. Environ. Sci. Technol. 1984, 18 (12), 358A-371A. https://doi.org/10.1021/es00130a001.

(13) Pelizzetti E., Calza P. (2002) Photochemical Processes in the Euphotic Zone of Sea Water: Progress and Problems. In: Gianguzza A., Pelizzetti E., Sammartano S. (eds) Chemistry of Marine Water and Sediments. Environmental Science. Springer, Berlin, Heidelberg. 
482

483

484

485

486

487

488

489

490

491

492

493

494

495

496

497

498

499

500

501

(14) Botta, C.; Labille, J.; Auffan, M.; Borschneck, D.; Miche, H.; Cabié, M.; Masion, A.; Rose, J.; Bottero, J. Y. $\mathrm{TiO}_{2}$-based Nanoparticles Released in Water from Commercialized Sunscreens in a Life-Cycle Perspective: Structures and Quantities. Environ. Pollut. 2011, 159 (6), 1543-1550. https://doi.org/10.1016/j.envpol.2011.03.003

(15) Said, M. A.; Gerges, M. A.; Maiyza, I. A.; Hussein, M. A.; Radwan, A. A. Changes in Atlantic Water Characteristics in the South-Eastern Mediterranean Sea as a Result of Natural and Anthropogenic Activities. Oceanologia 2011, 53 (1), 81-95. https://doi.org/10.5697/OC.53-1.081.

(16) Shaltout, M.; Omstedt, A. Recent Sea Surface Temperature Trends and Future Scenarios for the Mediterranean Sea. Oceanologia 2014, 56 (3), 411-443. https://doi.org/10.5697/OC.56-3.411.

(17) Bennet, F.; Hart-Smith, G.; Gruendling, T.; Davis, T. P.; Barker, P. J.; Barner-Kowollik, C. Supporting Information. Degradation of Poly(Methyl Methacrylate) Model Compounds Under Extreme Environmental Conditions. Macromol. Chem. Phys. 2010, 211, 1083. https://doi.org/10.1002/macp.200900625.

(18) Karl, L. G.; Mark, R.; Edward, M. J.; Ronald, E. D.; Forbes, P. D. Sun Protection Factor Testing: Comparison of Fda and Din Methods. J. Toxicol. Cutan. Ocul. Toxicol. 1987, 6 (4), 357-370. https://doi.org/10.3109/15569528709052181.

(19) Aguilera, J.; Gálvez, M. V. De; Conde, R.; Pérez-rodríguez, E.; Viñegla, B. Estudios Clínicos y de Laboratorio Series Temporales de Medida de Radiación Solar Ultravioleta y 
Fotosintética en Málaga. Actas. 2004, 95 (1), 25-31. https://doi.org/10.1016/S0001$7310(04) 79200-5$.

504

505

506

507

508

509

510

511

512

513

514

515

516

517

(20) Páscoa, R. N. M. J.; Tóth, I. V.; Almeida, A. A.; Rangel, A. O. S. S. Spectrophotometric Sensor System Based on a Liquid Waveguide Capillary Cell for the Determination of Titanium: Application to Natural Waters, Sunscreens and a Lake Sediment. Sensors Actuators B Chem. 2011, 157 (1), 51-56. https://doi.org/10.1016/J.SNB.2011.03.025.

(21) Grasshoff K and Almgreen T (1976) Methods of seawater analysis. Verlag Chemie. $344 \mathrm{p}$.

(22) Bruland, K. W.; Coale, K. H.; Mart, L. Analysis of Seawater for Dissolved Cadmium, Copper and Lead: An Intercomparison of Voltammetric and Atomic Absorption Methods. Mar. Chem. 1985, 17 (4), 285-300. https://doi.org/10.1016/0304-4203(85)90002-7.

(23) Martín-Torre, M.C.; Ruiz, G.; Galan, B.; Viguri, J.R. $\mathrm{CO}_{2}$ Seawater Acidification by CCSSimulated Leakage: Kinetic Modelling of $\mathrm{Zn}, \mathrm{Pb}, \mathrm{Cd}, \mathrm{Ni}, \mathrm{Cr}, \mathrm{Cu}$ and As from Contaminated Estuarine Sediment using pH-static leaching tests. Int. J. Greenh. Gas Control, 2016, 54, 185e199. http://dx.doi.org/10.1016/j.ijggc.2016.09.004.

(24) Martín-Torre, M.C.; Cifrian, E.; Ruiz, G.; Galán, B.; Viguri, J.R. Estuarine Sediment Resuspension and Acidification: Release Behaviour of Contaminants under Different Oxidation Levels and Acid Sources. J. Environ. Manage. 2017. 199, 211-221. https://doi.org/10.1016/j.jenvman.2017.05.044.

(25) Becker, L. C.; Boyer, I.; Bergfeld, W. F.; Belsito, D. V.; Hill, R. A.; Klaassen, C. D.; Liebler, D. C.; Marks, J. G.; Shank, R. C.; Slaga, T. J.; Snyder, R. C.; Andersen, F. A. Safety 
Assessment of Alumina and Aluminum Hydroxide as Used in Cosmetics. Int. J. Toxicol. 2016, 35 (3), 16S-33S. https://doi.org/10.1177/1091581816677948.

524

525

526

527

(26) McCall, M.J.; Gulson, B.; Andrews, D. (2018) Consumer Use of Sunscreens Containing Nanoparticles. In: Hull, M., Bowman, D (eds) Nanotechnology Environmental Health and Safety: Risks, Regulation, and Management. Elsevier, Cambridge, USA. Pp580.

(27) Osmond-McLeod, M. J.; Oytam, Y.; Rowe, A.; Sobhanmanesh, F.; Greenoak, G.; Kirby, J.; McInnes, E. F.; McCall, M. J. Long-Term Exposure to Commercially Available Sunscreens Containing Nanoparticles of $\mathrm{TiO}_{2}$ and $\mathrm{ZnO}$ Revealed No Biological Impact in a Hairless Mouse Model. Part. Fibre Toxicol. 2016, 13 (1), 1-13. https://doi.org/10.1186/s12989-016-0154-4.

(28) Siti Zulaikha, R.; Sharifah Norkhadijah, S. I.; Praveena, S. M. Hazardous Ingredients in Cosmetics and Personal Care Products and Health Concern: A Review. Public Heal. Res. 2015, 5 (1), 7-15. https://doi.org/10.5923/j.phr.20150501.02.

(29) Adepoju-Bello; Oguntibeju, O. O.; Adebisi, R. A.; Okpala, N.; Coker, H. A. B. Evaluation of the Concentration of Toxic Metals in Cosmetic Products in Nigeria. African J. Biotechnol. 2012, 11 (97), 16360-16364. https://doi.org/10.5897/AJB12.1411.

(30) Al-Saleh, I.; Al-Enazi, S. Trace Metals in Lipsticks. Toxicol. Environ. Chem. 2011, 93 (6), 1149-1165. https://doi.org/10.1080/02772248.2011.582040.

(30) De la Calle, I.; Menta, M.; Klein, M.; Séby, F. Screening of $\mathrm{TiO}_{2}$ and Au nanoparticles in cosmetics and determination of elemental impurities by multiple techniques (DLS, SP-ICP- 
542

543

544

545

546

547

548

549

550

551

552

553

554

555

556

557

558

559

560

561

562

MS, ICP-MS and ICP-OES). Talanta, 2017, 171, 291-306. https://doi.org/ 10.1016/j.talanta.2017.05.002.

(32) Michalun, M. V.; DiNardo, J. Skin Care and Cosmetic Ingredients Dictionary; 2014.

(33) Nafisi, S.; Schäfer-Korting, M.; Maibach, H. I. Perspectives on Percutaneous Penetration: Silica Nanoparticles. Nanotoxicology 2015, $\quad 9 \quad$ (5), 643-657. https://doi.org/10.3109/17435390.2014.958115.

(34) Kim, M.-K.; Lim, S.-K.; Suh, H.-S.; Kim, M.-H.; Baek, S.-H.; Lee, B.-M. Risk Assessment of Bis-Ethylhexyloxyphenol Methoxyphenyl Triazine in Cosmetic Products. Toxicol. Lett. 2017, 280, S103-S104. https://doi.org/10.1016/J.TOXLET.2017.07.287.

(35) Schneider, S. L.; Lim, H. W. Review of Environmental Effects of Oxybenzone and Other Sunscreen Active Ingredients. J. Am. Acad. Dermatol. 2019, 80 (1), 266-271. https://doi.org/10.1016/J.JAAD.2018.06.033.

(36) Suh, H. sun; Lim, S. kwang; Kim, M. kook; Kim, M. hwa; Baek, S. hwa. Risk Assessment of Ethylhexyl Triazone in Sunscreen Cosmetic Products. Toxicol. Lett. 2017, 280, S106. https://doi.org/10.1016/J.TOXLET.2017.07.296.

(37) Schakel, D. J.; Kalsbeek, D.; Boer, K. Determination of Sixteen UV Filters in Suncare Formulations by High-Performance Liquid Chromatography. J. Chromatogr. A 2004, 1049 (1-2), 127-130. https://doi.org/10.1016/J.CHROMA.2004.07.068.

(38) Tovar-Sánchez, A.; Basterretxea, G.; Rodellas, V.; Sánchez-Quiles, D.; García-Orellana, J.; Masqué, P.; Jordi, A.; López, J. M.; Garcia-Solsona, E. Contribution of Groundwater 
Discharge to the Coastal Dissolved Nutrients and Trace Metal Concentrations in Majorca Island: Karstic vs Detrital Systems. Environ. Sci. Technol. 2014, 48 (20), 11819-11827. https://doi.org/10.1021/es502958t.

(39) Ji, Y.; Zhou, L.; Zhang, Y.; Ferronato, C.; Brigante, M.; Mailhot, G.; Yang, X., Chovelon,

J-M. Photochemical Degradation of Sunscreen Agent 2- phenylbenzimidazole-5-sulfonic Acid in Different Water Matrices. Water Res. 2013, 47, 5865-5875. https://doi.org/10.1016/j.watres.2013.07.009

(40) Labille, J.; Feng, J.; Botta, C.; Borschneck, D.; Sammut, M.; Cabie, M.; Auffan, M.; Rose, J.; Bottero, J.-Y. Aging of TiO2 Nanocomposites Used in Sunscreen. Dispersion and Fate of the Degradation Products in Aqueous Environment. Environ. Pollut. 2010, 158 (12), 3482-3489. https://doi.org/10.1016/J.ENVPOL.2010.02.012.

(41) Goswami, L.; Kim, K.-H.; Deep, A.; Das, P.; Bhattacharya, S. S.; Kumar, S.; Adelodun, A.

A. Engineered Nano Particles: Nature, Behavior, and Effect on the Environment. J. Environ. Manage. 2017, 196, 297-315. https://doi.org/10.1016/J.JENVMAN.2017.01.011.

(42) Amde, M.; Liu, J.-F.; Tan, Z.-Q.; Bekana, D. Transformation and Bioavailability of Metal

Oxide Nanoparticles in Aquatic and Terrestrial Environments. A Review. Environ. Pollu. 2017, 230, 250-267. https://doi.org/10.1016/j.envpol.2017.06.064.

(43) Bundschuh, M.; Filser, J.; Lüderwald, S.; McKee, M. S.; Metreveli, G.; Schaumann, G. E.; Schulz, R.; Wagner, S. Nanoparticles in the Environment: Where Do We Come from, Where Do We Go To?. Environ. Sci. Eur. 2018, 30 (1), 6. https://doi.org/10.1186/s12302018-0132-6. 
584 (44) Low, G.K.-C.; McEvoy, S.R.; Matthews, R.W. Formation of Nitrate and Ammonium Ions

585

586 in Titanium Dioxide Mediated Photocatalytic Degradation of Organic Compounds Containing Nitrogen Atoms. Environ. Sci. Technol. 1991, 25, 460-467. https://doi.org/10.1021/es00015a013.

(45) Jing, J.; Liu, M.; Colvin, V. L.; Li, W.; Yu, W. W. Photocatalytic Degradation of NitrogenContaining Organic Compounds over $\mathrm{TiO}_{2}$. J. Mol. Catal. A Chem. 2011, 351, 17-28. https://doi.org/https://doi.org/10.1016/j.molcata.2011.10.002.

(46) Abdelraheem, W. H. M.; He, X.; Komy, Z. R.; Ismail, N. M.; Dionysiou, D. D. Revealing the Mechanism, Pathways and Kinetics of UV254nm/H2O2-Based Degradation of Model Active Sunscreen Ingredient PBSA. Chem. Eng. J. 2016, 288, 824-833. https://doi.org /10.1016/j.cej.2015.12.046.

(47) Corinaldesi, C.; Damiani, E.; Marcellini, F.; Falugi, C.; Tiano, L.; Brugè, F.; Danovaro, R. Sunscreen Products Impair the Early Developmental Stages of the Sea Urchin Paracentrotus lividus. Sci. Rep. 2017, 7 (1), 7815. https://doi.org/10.1038/s41598-01708013-X.

(48) Castro, M.; Fernandes, J. O.; Pena, A.; Cunha, S. C. Occurrence, Profile and Spatial Distribution of UV-Filters and Musk Fragrances in Mussels from Portuguese Coastline. Mar. Environ. Res. 2018, 138, 110-118. https://doi.org/10.1016/J.MARENVRES.2018.04. 005.

(49) Sureda, A.; Capó, X.; Busquets-Cortés, C.; Tejada, S. Acute Exposure to Sunscreen Containing Titanium Induces an Adaptive Response and Oxidative Stress in Mytillus 
galloprovincialis. Ecotoxicol. Environ. Saf. 2018, $149, \quad 58-63$. https://doi.org/10.1016/J.ECOENV.2017.11.014.

607

608

609

610

611

612

613

614

615

616

617

618

619

620

621

622

623

624

(50) Vidal-Liñán, L.; Villaverde-de-Sáa, E.; Rodil, R.; Quintana, J. B.; Beiras, R. Bioaccumulation of UV Filters in Mytilus galloprovincialis Mussel. Chemosphere 2018, 190, 267-271. https://doi.org/10.1016/j.chemosphere.2017.09.144.

(51) Diffey, B. Has the Sun Protection Factor Had its Day? BMJ 2000, 320 (7228), 176-177. https://doi.org/10.1136/bmj.320.7228.176

(52) Danovaro, R.; Bongiorni, L.; Corinaldesi, C.; Giovannelli, D.; Damiani, E.; Astolfi, P.; Greci, L.; Pusceddu, A. Sunscreens Cause Coral Bleaching by Promoting Viral Infections. Environ. Health Perspect. 2008, 116 (4), 441-447. https://doi.org/10.1289/ehp.10966.

(53) Sánchez-Quiles, D.; Tovar-Sánchez, A. Sunscreens as a Source of Hydrogen Peroxide Production in Coastal Waters. Environ. Sci. Technol. 2014, 48 (16), 9037-9042. https://doi.org/10.1021/es5020696.

(54) Fraústo da Silva, J. J. R.; Williams, R. J. P. The Biological Chemistry of the Elements-The Inorganic Chemistry of Life; 1991. Clarendon, Oxford, U. K.

(55) Morel, F. M. M.; Price, N. M. The Biogeochemical Cycles of Trace Metals in the Oceans. Science 2003, 300, 944-947, https://doi:10.1126/science.1083545.

(56) Echeveste, P.; Agusti, S.; Tovar-Sánchez, A. Toxic Thresholds of Cadmium and Lead to Oceanic Phytoplankton: Cell Size and Ocean Basin-Dependent Effects. Environ. Toxicol. and Chem. 2012, 31(8), 1887 - 894. https://doi.org/10.1002/etc.1893. 
625 (57) Golding, L. A.; Angel, B. M.; Batley, G. E.; Apte, S. C.; Krassoi, R.; Doyle, C. J. Derivation of a Water Quality Guideline for Aluminium in Marine Waters. Environ. Toxicol. Chem. 2015, 34 (1), 141-151. https://doi.org/10.1002/etc.2771.

(58) Krom, M. D.; Kress, N.; Brenner, S.; Gordon, L. I. Phosphorus Limitation of Primary Productivity in the Eastern Mediterranean Sea. Limnol. Oceanogr. 1991, 36 (3), 424-432. https://doi.org/doi:10.4319/1o.1991.36.3.0424.

(59) Thingstad, T. F.; Zweifel, U. L.; Rassoulzadegan, F. P Limitation of Heterotrophic Bacteria and Phytoplankton in the Northwest Mediterranean. Limnol. Oceanogr. 1998, 43 (1), 8894. https://doi.org/10.4319/1o.1998.43.1.0088.

(60) Thingstad, T. F.; Krom, M. D.; Mantoura, R. F. C.; Flaten, G. A. F.; Groom, S.; Herut, B.; Kress, N.; Law, C. S.; Pasternak, A.; Pitta, P.; Parra, S.; Rassoulzadegan, F.; Tanaka, T.; Tselepides, A.; Wassmann, P.; Woodward, E. M. S.; Wexels Riser, C.; Zodiatis, G.; Zoharg, T. Nature of Phosphorus Limitation in the Ultraoligotrophic Eastern Mediterranean.

(61) Van Wambeke, F.; Catala, P.; Pujo-Pay, M.; Lebaron, P. Vertical and Longitudinal Gradients in HNA-LNA Cell Abundances and Cytometric Characteristics in the Mediterranean Sea, Biogeosciences. 2011, 8, 1853-1863. https://doi.org/10.5194/bg-8-1853-2011.

(62) Basterretxea, G.; Garcés, E.; Jordi, A.; Anglès, S.; Masó, M. Modulation of Nearshore Harmful Algal Blooms by in Situ Growth Rate and Water Renewal. Mar. Ecol. Prog. Ser. 2007, 352, 53-65. https://doi.org/10.3354/meps07168. 
645 (63) Whitehead, R. F.; de Mora, S. J.; Demers, S. Enhanced of UV Radiation-a New Problem 646 for the Marine Environment. In The effects of UV radiation in the marine environment; De Mora, S., Demers, S., Vernet, M., Eds.; 2000. https://doi.org/10.1017/CBO9780511535444.

(64) Wrona, F.J.; Prowse, T.D.; Reist, J.D.; Hobbie, J.E.; Lévesque, L.M.; Macdonald, R.W.; Vincent, W.F. Effects of Ultraviolet Radiation and Contaminant-related Stressors on Arctic Freshwater Ecosystems. Ambio. 2006, 35(7):388-401. ttps://doi.org/10.1579/0044-7447

(65) Donia, D.; Carbone, M. Fate of the Nanoparticles in Environmental Cycles. Int. J. Environ. Sci. Technol. 2018, 16, 583-600. https://doi.org/10.1007/s13762-018-1960-z.

(66) Haynes, V.N.; Ward, J.E.; Russell, B.J.; Agrios, A.G. Photocatalytic Effects of Titanium

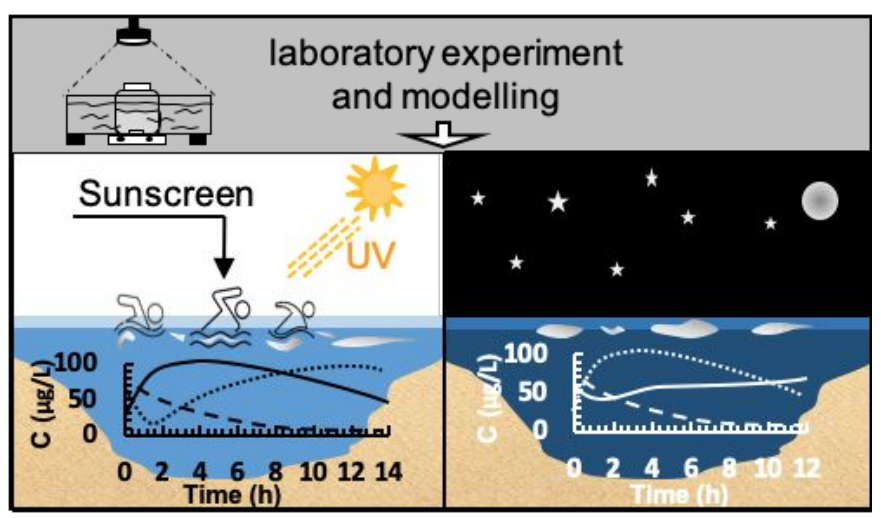

